\title{
THE ROLE OF TOPOGRAPHY, CANOPY GAPS, AND FOREST EDGES IN THE DISTRIBUTION OF WINDTHROW DAMAGE IN THE WESTERN TATRA MOUNTAINS, POLAND
}

\section{Dariusz Strzyżowski}

Institute of Geography and Spatial Management

Jagiellonian University

Gronostajowa 7, 30-387 Kraków: Poland

e-mail: dariusz.strzyzowski@doctoral.uj.edu.pl

\begin{abstract}
Windthrows are ubiquitous in forest environments, and they lead to many ecologic, pedologic, and geomorphic consequences. The distribution of wind damage is not uniform, and may be controlled by many factors. This study examines the role of topography, canopy gaps, and forest edges in the distribution of windthrow damage within the Polish part of the Western Tatra Mountains $\left(121.7 \mathrm{~km}^{2}\right)$. A set of aerial photographs was used to map windthrows created in 4 different periods: before 2009, 2009-2012, 2012-2014, and 2014-2015. GIS mapping, image classification, and $t$-test were applied to analyze the data. Among all topographic characteristics, the highest diversification of windthrow distribution was observed in the case of aspect, which was probably connected with different wind directions in analyzed periods. Slope and elevation also controlled damage distribution, mainly by a decreased damage within the steepest slopes and the highest elevations. Canopy gaps did not influence damage distribution significantly. Forest edges, particularly those created by recent windthrow, were the most important factor influencing the distribution of wind damage.
\end{abstract}

\section{Key words}

forest damage $\bullet$ wind $\cdot$ GIS analysis $\bullet$ spatial pattern $\bullet$ topography $\bullet$ canopy gaps $\bullet$ forest edge - Tatra National Park

\section{Introduction}

Damage in the forest stands caused by strong wind is a very common phenomenon occurring within almost all forested areas (Schaetzl et al. 1989a). As a result of wind, trees may be uprooted or broken. The aerial extent of damage may depend on the type of a wind event (Phillips et al. 2015) as well as its intensity (Frelich \& Lorimer 1991). During low intensity events small gaps in the canopy may be created, while during high 
intensity events extensive forest areas may be damaged (Schaetzl et al. 1989b).

The process of windthrow leads to many environmental consequences. Depending on the abovementioned intensity it may cause the replacement of single or small groups of trees, or a whole forest stand (Ulanova 2000). If damaged trees are uprooted, pit and mound features are created (Denny \& Goodlett 1956; Putz 1983; Norman et al. 1994). This results in the mixing of soil, changes in the soil properties, and the creation of different microsites (Phillips \& Marion 2004; Šamonil et al. 2010), which in turn may control the process of regeneration (Clinton $\&$ Baker 2000). The uprooting of trees also promotes biomechanical soil weathering (Phillips et al. 2005; Gabet \& Mudd 2010), and causes the transporting of sediment which in the longer timescales leads to the denudation of hillslope (Pawlik et al. 2016; Phillips et al. 2017; Strzyżowski et al. 2018).

The distribution of windthrow damage is not uniform across a landscape (Cremeans \& Kalisz, 1988). Thus, considering all windthrow consequences, the determination of factors which control the spatial distribution of wind damage seems to be an important issue, not only for the purpose of forest management, but also for a better understanding of the relations between different components of the forest environment.

Factors which influence the distribution of windthrow damage may be both biotic, and abiotic (Everham \& Brokaw 1996). Biotic factors may include tree parameters, such as diameter, height, crown shape, root system architecture, or wood strength (Cremer et al. 1982; Peterson 2007), and forest stand parameters, such as tree density, age, species diversity, or condition of trees (Papaik et al. 2005; Evans et al. 2007). Abiotic factors incorporate topography, wind exposure, wind strength, soil and bedrock properties, and amount of rainfall (Kotarba 1970; Bzowski \& Dziewolski 1973; Ruel et al. 1998; Kulakowski \& Veblen 2002; Lenart et al. 2010). However, the results of the studies, especially those considering the role of topography in the damage distribution, are not always unequivocal. For example some studies showed a positive relation between the amount of damage and the elevation (Evans et al. 2007; Lenart et al. 2010), while others indicated higher damage at lower topographic positions (Cremeans \& Kalisz 1988). Frelich \& Lorimer (1991) on the other hand pointed out that topography has no significant influence on the damage distribution.

Wind damage may be also promoted by the presence of forest gaps, and forest edges (Cremer et al. 1982; DeWalle 1983; Stacey et al. 1994; Gardiner et al. 1997). However, their contribution to windthrow may be considerably lower if trees become adopted to new, more windy conditions (Cremer et al. 1977; Stacey et al. 1994).

In this study an examination of factors which influenced the spatial distribution of wind damage is conducted. The investigation is based on different-age aerial photographs of the Western Tatra Mountains, the area which systematically encounters strong wind events. GIS methods are used to analyze damage distribution in four different periods. The main goals of the study are to: (1) define how and to what extent the distribution of wind damage was influenced by topographic features, such as: aspect, slope inclination, and elevation; (2) determine the role of forest canopy gaps, and forest edges in the distribution of windthrow damage.

\section{Study area}

The study was conducted within the Polish part of the Western Tatra Mountains $\left(121.7 \mathrm{~km}^{2}\right)$, in the Tatra National Park. The Tatra Mountains are the highest mountain range in the Carpathians. The highest peaks reach a height of over $2500 \mathrm{~m}$ a.s.l. The southern, much higher elevated, part of the Polish Western Tatra Mountains is characterized by glacial and periglacial relief, which developed during the Pleistocene, while the northern part of the area has typical fluviodenudational relief (Klimaszewski 1972). The southern part of the Western Tatra Mountains 
is built of metamorphic rocks, mostly gneiss, schist, migmatite, and amphibolite. The valleys in this part of the massif are filled with moraine deposits and fluvioglacial deposits. The northern part of the Western Tatra Mountains is built of sedimentary rocks, mostly limestone, dolomite, marl, sandstone, and conglomerate. The valley bottoms at that area are filled with alluvial deposits (Bac-Moszaszwili et al. 1979). Dominant soil types within the forested part of the area include: Umbric-Rendzic Leptosols, Cambic-Rendzic Leptosols, Eutric Cambisols, and Orthic Podzols (Skiba 2002).

Mean annual temperature is $4^{\circ} \mathrm{C}$ at $1150 \mathrm{~m}$ a.s.l., and $-2^{\circ} \mathrm{C}$ at $2200 \mathrm{~m}$ a.s.l. (Hess 1974). Mean annual rainfall is $1400 \mathrm{~mm}$, at $1150 \mathrm{~m}$ a.s.l., and reaches $1750 \mathrm{~mm}$ at the height of $2000 \mathrm{~m}$ a.s.l. (Hess 1974). The Tatra Mountains are characterized by frequent foehn wind events, which mostly occur between October and May, and their dominant direction is from the south (Niedźwiedź 1992). These winds cause significant damage in the forest cover. They may occasionally reach a speed above $60 \mathrm{~m} \cdot \mathrm{s}^{-1}$ (Niedźwiedź 1992). Recently the most catastrophic windthrow events caused by foehn winds occurred in 1968, and in 2013, leading to the destruction of respectively 469 , and 298 ha of the Tatra National Park forests
(Bzowski \& Dziewolski 1973; Strzyżowski et al. 2018).

Natural forest structure in the Tatra Mountains should consist of deciduous forest belt up to the height of $1200 \mathrm{~m}$ a.s.l. and coniferous forest belt reaching the upper timber line at the height of $1550 \mathrm{~m}$ a.s.l. (Mirek 1996). The forests of the Tatra Mountains, however, were subject to intense logging and pasturing, which continued until the establishing of the Tatra National Park in 1954 (Ciurzycki 2003). The long period of this human impact led to substantial changes, especially in the structure of the lower forest belt. At the present state the forests of the Tatra Mountains are mostly composed of spruce which constitutes $92 \%$ of the whole forest cover in the Tatra National Park (Krameko sp. z o.o. 2005).

\section{Methods}

For the purpose of the analysis orthophotos taken in 2009 (CODGiK 2017a), 2012 (Tatra National Park data), 2015 (CODGiK 2017a), and satellite imagery taken in 2014 (WorldView-2; analyses were conducted in the Department of Research and Nature Conservation Management of the Tatra National Park) were used. The resolution of the images ranged between 0.2 and $0.5 \mathrm{~m}$ (Fig. 1). At first, all windthrow areas visible on those

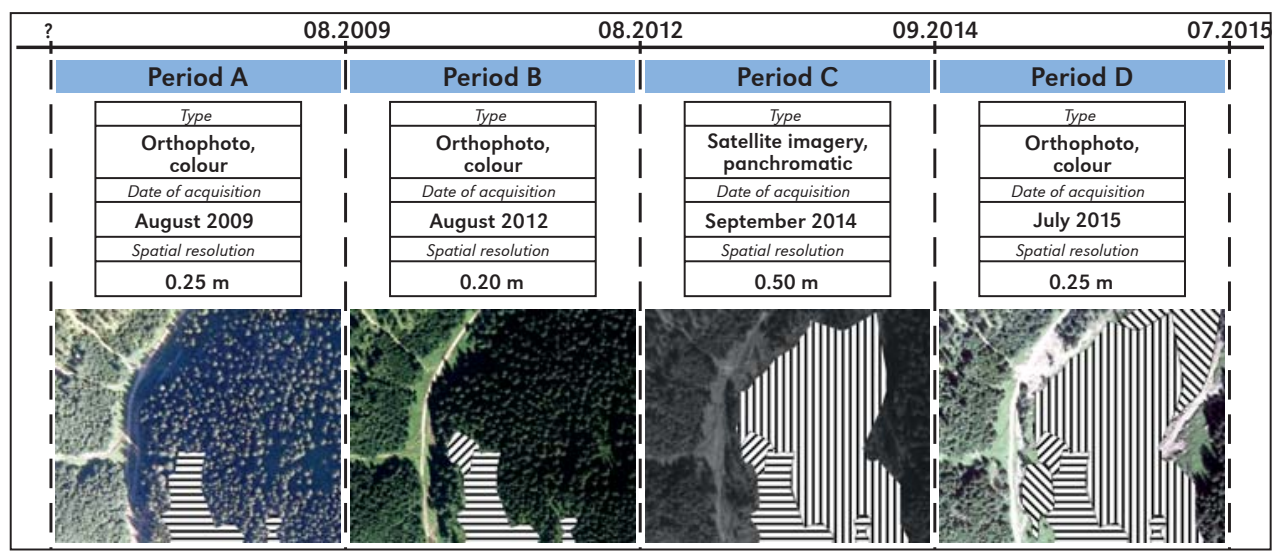

Figure 1. Scheme presenting the time intervals of 4 monitoring periods, and the parameters of the aerial photographs used for the purpose of the analysis 
images and located within the Polish part of the Western Tatra Mountains $\left(121.7 \mathrm{~km}^{2}\right)$ were digitized. As a result windthrows created in 4 different periods, i.e. before 2009 (period A), between 2009 and 2012 (period B), between 2012 and 2014 (period C), and between 2014 and 2015 (period D), were mapped. For all of those periods, excluding the period $A$, the time span during which windthrows were created was known with an accuracy of one month (Fig. 1). In the case of the period $A$, however, there was no sufficient data before the time of taking the first orthophoto (2009), so the time span during which those windthrow areas were created is not known.

There were some uncertainties during distinguishing windthrow areas created in the particular analyzed periods. Windthrow events frequently trigger an invasion of barkbeetle (Økland et al. 2016; Havašová et al. 2017), and thus, for the purpose of nature conservation, the Tatra National Park conducts logging operations within some of the windthrow areas. The operations include salvage logging of fallen trees (root plates are left in the field), and logging of dead, weakened, or bark beetle-affected trees. In spite of that, it was not always clear if an area which has been devoid of forest cover (when compared to the previous imagery) has been affected by windthrow or by logging operations. Hence, all the areas of reduced forest cover within which there were no apparent signs of fallen trunks or root plates were excluded from the analysis.

Area of the Polish part of the Western Tatra Mountains include both forested and unforested (e.g., dwarf pine belt, alpine belt) sites. For the purpose of the following analysis a shapefile containing only the area of the forest cover $\left(84.2 \mathrm{~km}^{2}\right)$ was prepared based on the Forest Data Bank of the State Forests Holding (Forest Data Bank 2017). To determine if aspect, slope, or elevation influenced the distribution of windthrow damage, the following procedure was conducted separately for each analyzed period (A, B, C, and $D)$. Based on the digital elevation model
(3 $\times 3$ m resolution; CODGiK 2017b), the area of forest cover $\left(84.2 \mathrm{~km}^{2}\right)$ was divided into intervals of aspect $\left(0-360^{\circ}, 24\right.$ intervals), slope $\left(0-53^{\circ}, 18\right.$ intervals), and elevation (892-1550 $\mathrm{m}$ a.s.l., 13 intervals). Then it was calculated what proportion of a forest area located within each interval of aspect, slope, and elevation was affected by windthrow damage.

To determine the role of canopy gaps in the distribution of windthrow damage the proportion of canopy gaps within the prewindthrow areas and within their surroundings was analyzed. This analysis, therefore, required the comparison of each windthrow site with its state before the windthrow creation (previous imagery). For each analyzed pre-windthrow area, a reference area was delineated, which surrounded the given pre-windthrow area, or was located within its direct vicinity. Each reference area was delineated in a topographic position similar to the position of a given pre-windthrow area and was at least as large as a given prewindthrow area. Then an appropriate orthophoto was clipped to each pre-windthrow and its reference area, and each of those pairs was classified using 'Maximum Likelihood Classification' tool in ArcGIS 10.2. Two classes were distinguished: forests (trees) and canopy gaps (shaded areas among trees). Bands 1, 2, and 3 were used, since only those were available for the analyzed imageries. In most of the clipped orthophoto fragments only tree crowns and canopy gaps were present, and therefore, the classification was simple, and its accuracy was satisfactory. There were some cases in which unshaded meadows were difficult to distinguish from trees during the classification. In such situations corrections in the area of canopy gaps were made manually after the classification. Finally, shapefiles presenting the area of trees and canopy gaps for each pre-windthrow and reference area were generated. Based on these, the percentage of an area occupied by canopy gaps was calculated both for the pre-windthrow areas and for their reference areas. To check if the percentage of canopy 
gaps differed significantly between the prewindthrow areas and their reference areas, a $t$-test for two independent samples was applied for $p=0.05$. To avoid biases in the results, all pre-windthrow areas which were classified as being created within the edge of the forest were excluded form this analysis, assuming that the effect of the forest edge may obscure the role of canopy gaps. Also all pre-windthrow areas were excluded for which finding a reference area characterized by a similar topographic position was impossible. Because of lack of data before 2009, and owing to the low quality of the satellite imagery taken in 2014, this analysis was conducted for periods B, and C.

To check the role of forest edges in the creation of windthrow damage, all windthrow areas digitized based on a given image were compared with the state of those sites presented by a previous image (before windthrow creation). For all of those pre-windthrow patches, the length of their perimeter, along which they were bordered (in the pre-windthrow period) by a no-forest area (meadow, recent windthrow, etc.) was measured. The percentage of this length in the length of the whole perimeter of a given pre-windthrow area was calculated. While no sufficient data before 2009 (first digitized windthrow areas - period A) was available, this analysis was conducted for periods $B, C$, and $D$.

\section{Results}

The magnitude of windthrow damage differed among the four analyzed periods
(Tab. 1). The most extensive damage was noted in the period C (nearly 300 ha of damage), when an extreme windthrow event occurred in December 2013. Totally, in all analyzed periods, 401.3 ha of forest were destroyed (Fig. 7A), which constitute 4.7\% of the whole forest cover of the Polish part of the Western Tatra Mountains.

Generally there is no unequivocal pattern of windthrow damage distribution according to aspect, slope, and elevation. It appears, however, that each of those topographic characteristics influenced the distribution of windthrow to a certain extent.

The percentage of the forest area affected by windthrow was highly diversified by the aspect (Fig. 2). In the period A windthrows affected mostly forests located within W, $\mathrm{N}$, and NE slopes. A similar situation was observed in the period $B$ - the most extensive damage was noted on slopes W, NE, and partly E. Different damage distribution occurred within the period C. In this case the largest damage was noted within $S$ and E slopes. In the period D forests were generally affected within $\mathrm{W}$ slopes, and exceptionally high damage occurred within W, SW, and NW exposures.

Analyzing the distribution of windthrow damage among different slope inclination intervals, some general trends may be noted. In all the analyzed periods the lowest proportion of damage was noted within the highest slope inclination intervals (Fig. 3). This is particularly pronounced in the periods A, B, and D, and somewhat less significant in the period $C$. The lowest slope

Table 1. Windthrow areas created in 4 analyzed periods

\begin{tabular}{|l|c|c|c|}
\hline Period & $\begin{array}{c}\text { Monitoring length } \\
{[\text { months] }}\end{array}$ & $\begin{array}{c}\text { Area of windthrows } \\
{[\text { ha] }}\end{array}$ & $\begin{array}{c}\text { Proportion of damaged } \\
\text { forest [\%] }\end{array}$ \\
\hline Period A & Unknown & 68.6 & 0.8 \\
Period B & 36 & 32.1 & 0.4 \\
Period C & 25 & 286.3 & 3.4 \\
Period D & 10 & 14.3 & 0.2 \\
\hline Total & $>71$ & 401.3 & 4.7 \\
\hline
\end{tabular}




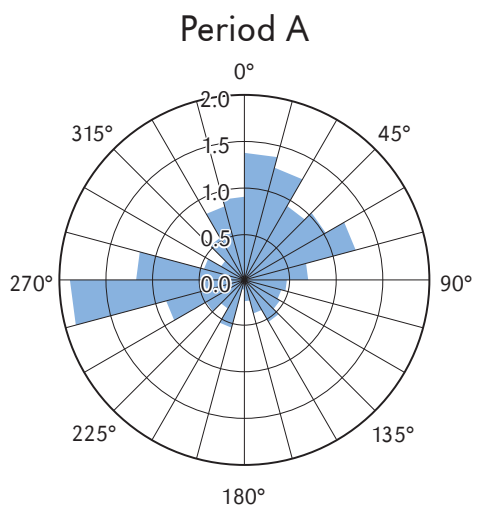

Period C

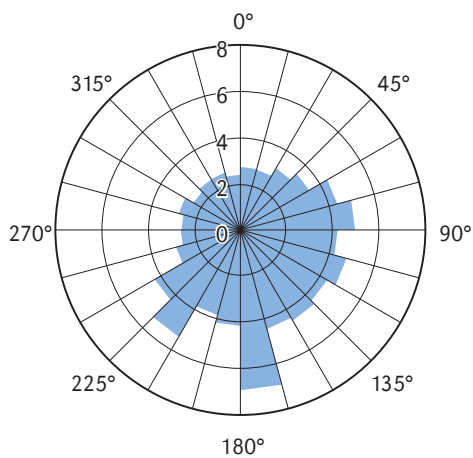

\section{Period B}

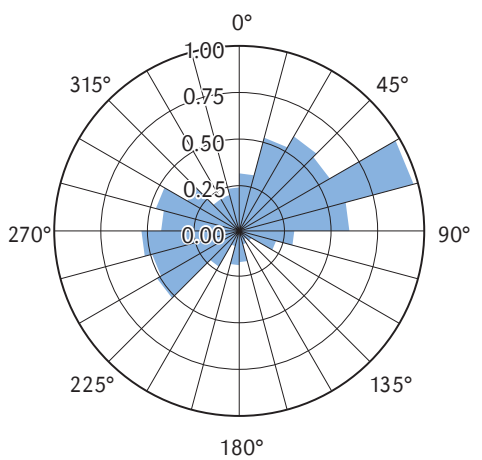

Period D

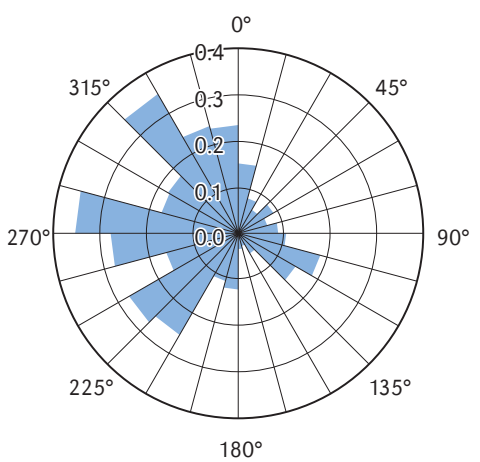

Figure 2. Percentage of the forest cover area of the Western Tatra Mountains affected by windthrows within 24 aspect intervals. Data is presented for 4 analyzed periods

inclinations in the period $\mathrm{A}\left(0-8^{\circ}\right), \mathrm{C}\left(0-11^{\circ}\right)$, and in the period $\mathrm{D}\left(0-5^{\circ}\right)$ also encountered a significantly lower proportion of windthrow damage than other slope intervals. However, this situation did not occur in the period $B$. Within three analyzed periods (A, B, and $C$ ) the largest proportion of windthrows was observed on slopes between 18 and $28^{\circ}$. Within the period $D$, however, the largest damage was noted on slopes $9-11^{\circ}$.

Distribution of windthrow damage among different elevation intervals is not uniform. Both the lowest and the highest elevations experienced a lower proportion of damage in all analyzed periods (Fig. 4). Three of the periods (B, C, D) are characterized by very similar damage distribution, with the most extensive windthrow areas located within the height of 1000-1150 m a.s.l., and the lowest proportion of damage above 13001350 m a.s.I. A somewhat different pattern of damage distribution was noted in the period $A$, in which the largest damage was noted within the elevation of $1250-1400 \mathrm{~m}$ a.s.l.

The analysis of the percentage of canopy gaps within the pre-windthrow areas and their reference areas, conducted for the periods $B$ and $C$, did not show any unequivocal pattern. In the period $B$ the percentage of an area occupied by canopy gaps was slightly lower within pre-windthrow areas than within their surroundings. However, in the period $C$ the situation was reversed (Fig. 5). Nevertheless, the differences in both periods are not significant $(p>0.05)$.

Analysis of the pre-windthrow sites showed that $63 \%, 56 \%$, and $88 \%$ of the windthrow areas digitized respectively for the period $B$, 

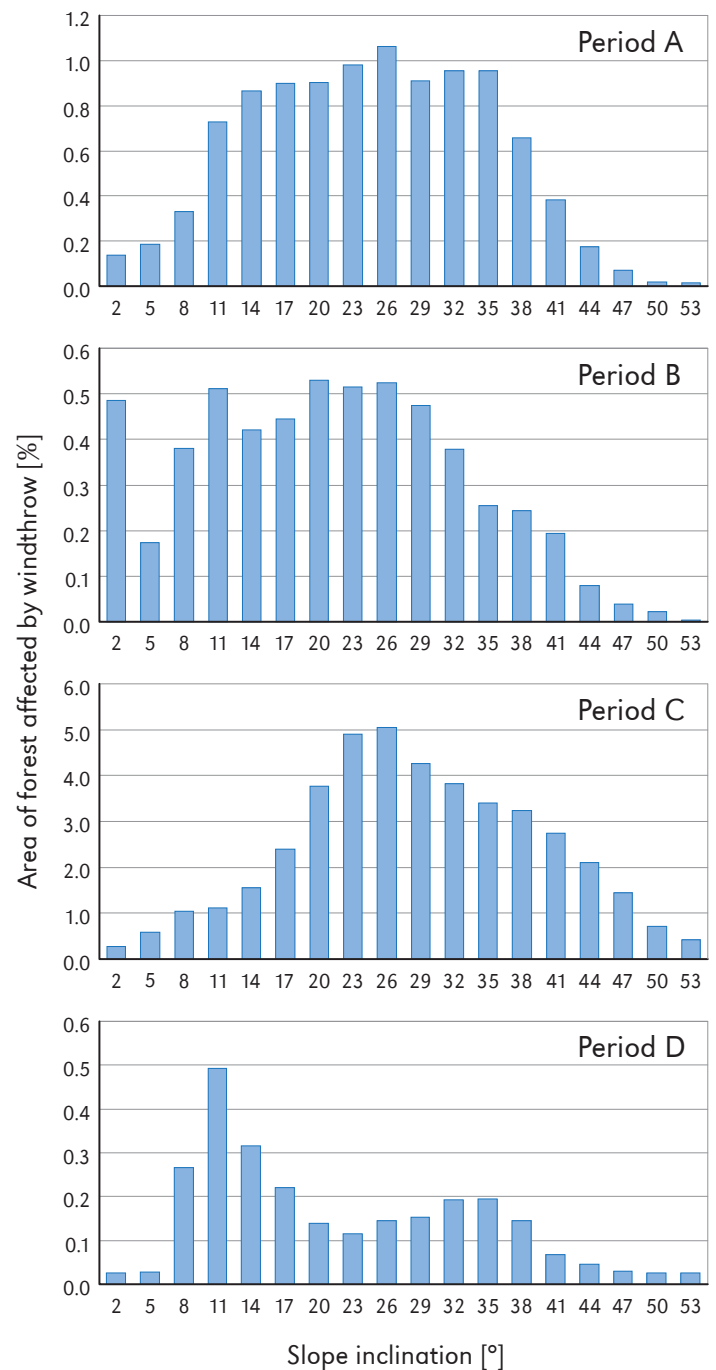

Figure 3. Percentage of the forest cover area of the Western Tatra Mountains affected by windthrows within 18 slope inclination intervals. The signatures under $x$ axis means the upper boundary of a given slope interval. Data is presented for 4 analyzed periods

$\mathrm{C}$, and $\mathrm{D}$ were created at the edges of the forest (Tab. 2). In 41\% (period B), 35\% (period C), and $67 \%$ (period D) of cases, the length along which those pre-windthrow areas bordered with the no-forest area was larger than 20\% of their perimeter (Fig. 6).

The spatial distribution of the differentage windthrow patches suggests that the location of damage in the forests may be frequently controlled by the placement of recently created windthrows. For the periods $B, C$, and $D$ respectively, 41,36 , and $88 \%$ of the digitized windthrow areas were created in the direct vicinity of recent windthrows (Tab. 2). Thus, the creation of a windthrow in a given period was frequently followed by the enlargement of that windthrow site in the following period, which results in the spatial clustering of windthrow patches (Fig. 7B). 

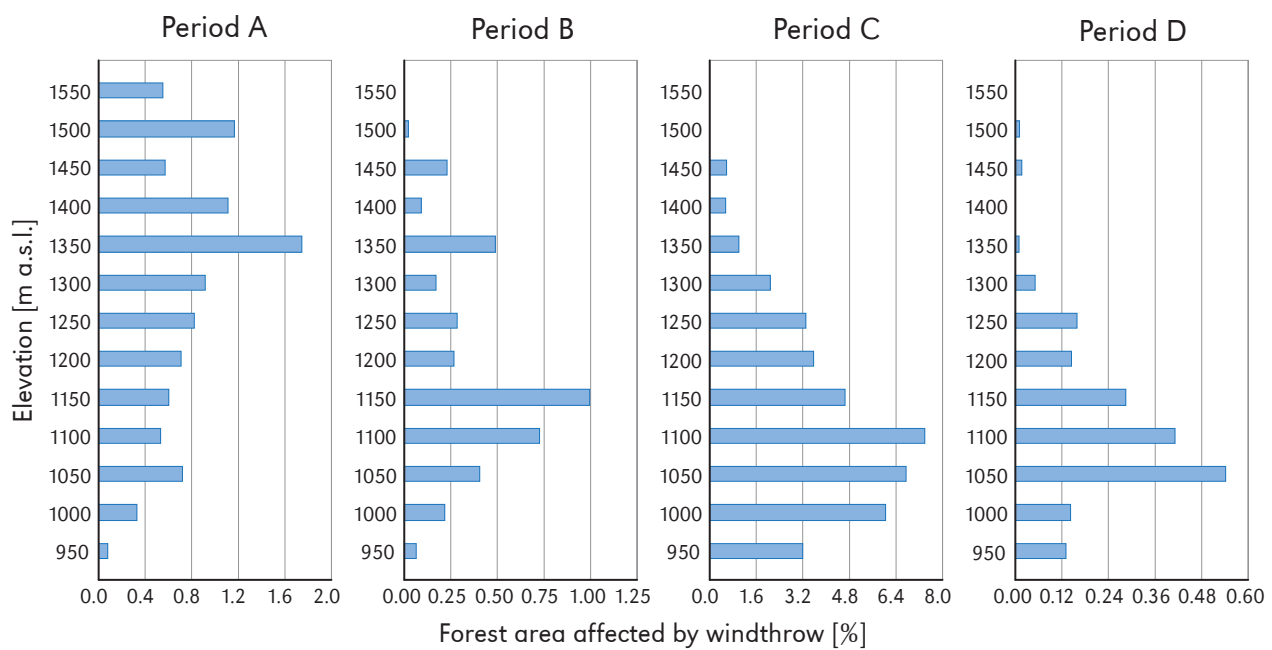

Figure 4. Percentage of the forest cover area of the Western Tatra Mountains affected by windthrows within 13 elevation intervals. The signatures next to the $y$ axis means the upper boundary of a given elevation interval. The lower boundary of the first interval is $892 \mathrm{~m}$ a.s.l. Data is presented for 4 analyzed periods
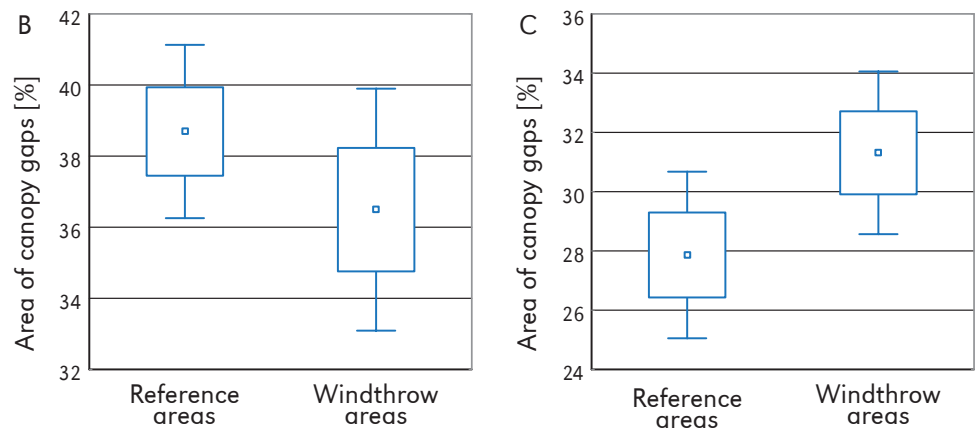

Figure 5. Results of the t-test showing the differences in the area of forest canopy gaps between windthrow areas (before their creation), and their reference areas for the periods $B$, and $C$. The same letters means no statistically significant differences at $p=0.05$. The dot inside the box is mean. The lower and upper edge of the box denote mean \pm SE. The lower and upper horizontal bars represent mean $\pm 1.96 \mathrm{SE}$

Table 2. Number of digitized windthrow areas created in the direct vicinity of no-forest area

\begin{tabular}{|l|c|c|c|}
\hline Period & $\begin{array}{c}\text { Windthrow areas } \\
\text { neighboring recent } \\
\text { windthrows } \\
{[\%]}\end{array}$ & $\begin{array}{c}\text { Windthrow areas } \\
\text { neighboring } \\
\text { grasslands } \\
{[\%]}\end{array}$ & $\begin{array}{c}\text { Total } \\
{[\%]}\end{array}$ \\
\hline Period B & 41 & 22 & 63 \\
Period C & 36 & 20 & 56 \\
Period D & 88 & 0 & 88 \\
\hline
\end{tabular}




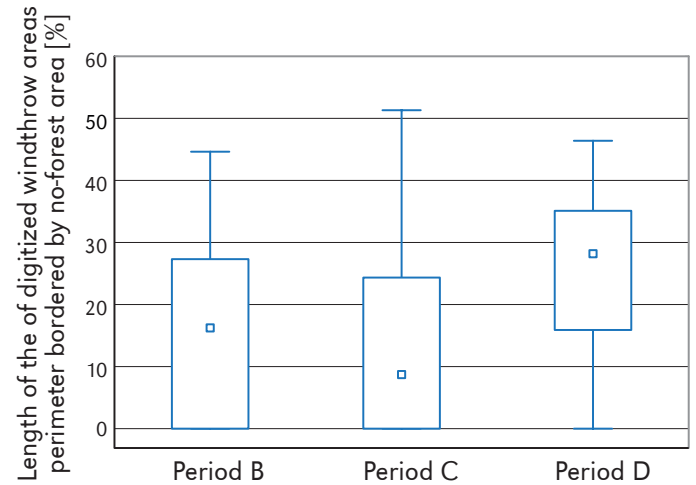

Figure 6. Box plot showing the distribution of the lengths of the digitized windthrow areas perimeter (as percentage) along which they were (before windthrow creation) bordered by no-forest area. Data is shown separately for three analyzed periods (A, B, and C). The dot inside the box is median. The lower and upper edge of the box denote 30th and 70th percentile. The lower and upper horizontal bars represent 10 th and 90 th percentile

\section{Discussion}

Topography may exert a considerable influence on the distribution of wind damage in the forests. In this research the most diversifying feature among all the analyzed topographic characteristics is the aspect. Different analyzed periods present different damage distribution according to the aspect, which may be connected with variability in the meteorological conditions during which windthrows were created. However, to determine meteorological conditions, the exact date of the given windthrow creation is needed, which is known only for the period C, in which almost the entire damage was created by one foehn wind event. During several hours of this event the direction of the wind ranged from 154 to $211^{\circ}$ (IMWM data), and the largest damage was noted in the forests exposed to the south, which means that windward slopes were affected to a larger degree than lee slopes. This is contrary to the results presented by Sokołowski (1934) and Bzowski \& Dziewolski (1973) who also analyzed the damage in the forests of the Tatra Mountains, and showed that windthrows were created mostly within lee slopes. Such relation was also noted by Jane (1986) who found higher damage within lee slopes in the forests of New Zealand. However, the flow of wind through a mountain area may be very complex, and significant deflections from the general wind direction may be noted (Kwiatkowski 1969; Kotarba 1970; Ruel et al. 1998; Clinton \& Baker 2000). There were cases, in which little damage occurred within lee slopes, because the wind was deflected and flowed over those slopes (Foster \& Boose 1992). Such a phenomenon may occur frequently within steep slopes (Sokołowski 1934; Bzowski \& Dziewolski 1973). It may have, for example, influenced the distribution of windthrow damage which occurred in November 2004 within the southern slopes of the Tatra Mountains in Slovakia, where $120 \mathrm{~km}^{2}$ of forests were destroyed by the northern wind. The damage occurred below 1250 m a.s.l., where the slopes become more gentle. The steepest slopes, above that height, avoided severe damage, which may be a result of abovementioned deflection of wind direction over steep slopes (Balon \& Maciejowski 2005; Faltan et al. 2009; Minár et al. 2009).

On the other hand, trees growing within lee slopes may be more susceptible to windthrow compared to windward slopes, where trees are more adapted to the action of wind (Jane 1986). Moreover, tree pulling 


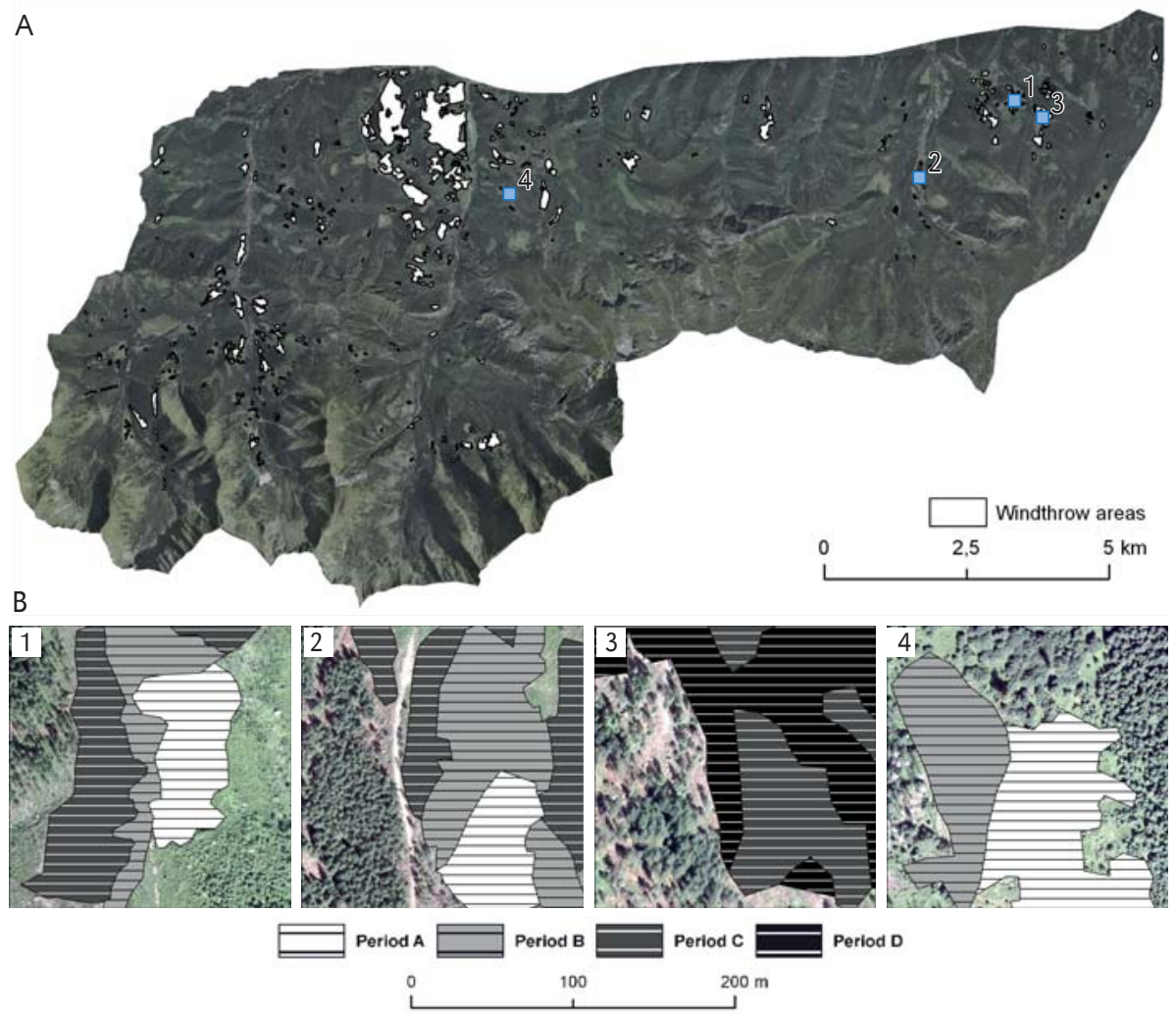

Figure 7. Map showing the distribution of all windthrow sites created during analyzed periods (a). Examples of windthrow areas which were enlarged by subsequent windthrow events in the following analyzed periods (b)

experiments on Sitka spruce showed that overturning a tree in a downslope direction requires significantly lower force than overturning it in an upslope direction (Nicoll et al. 2005). It appears then, that there is no rule as to whether lee or windward slopes are more susceptible to windthrow. During an extreme foehn wind event in the Tatra Mountains in 1968 (Bzowski \& Dziewolski 1973) the direction of the wind ranged from SSE to SW, similarly to the event in 2013 (period C). However, the mean velocity of the wind in 1968 was up to $50 \mathrm{~m} \cdot \mathrm{s}^{-1}$ (Bzowski \& Dziewolski 1973), which was significantly higher compared to the event in $2013\left(29 \mathrm{~m} \cdot \mathrm{s}^{-1}\right.$; IMWM data). It may be that a difference in meteorological conditions, here mainly expressed by a different wind strength, led to different wind deflections, and in the one case (1968) lee slopes, and in the other (2013, period C) windward slopes were mostly damaged. Nevertheless, for a more comprehensive explanation of the role of aspect in wind damage distribution, a larger data set would be required. Unfortunately, in the case of many windthrow areas there is no data on the meteorological conditions during which they were created which underlines a need of further windthrow monitoring.

There is limited information in the literature on the role of slope inclination in the distribution of windthrow damage. Some of the authors observed no clear relation between slope inclination and the distribution of damage in the forests (Greenberg \& McNab 1998; Kramer et al. 2001), and some found 
a significant increase in the proportion of damaged trees with increasing slope (Lenart et al. 2010). One of the important relations, mentioned earlier, is the deflection of wind within steep lee slopes, which may result in low damage (Sokołowski 1934; Bzowski \& Dziewolski 1973). In this study an explicit decrease in the proportion of damage was noted within the steepest slopes (above $41^{\circ}$ ), which is slightly less pronounced in the case of the period C. This may be evidence of wind deflection which causes sheltering of the steepest lee slopes. It may be also caused by the low angle between the surface, and the wind direction, which may cause wind to blow more parallel to the axis of tree trunks, both within lee and windward slopes, and thus wind pressure at a given tree is lower. Such relationship was pointed out by Balon \& Maciejowski (2005), who assumed that this may be one of the reasons why steep slopes avoided forest damage during severe windthrow in the Slovakian Tatra Mountains in 2004.

Different remarks were noted on the role of elevation in the distribution of wind damage in the forests. Cremeans \& Kalisz (1988) showed that the proportion of uprooted trees was higher within lower topographic positions than within ridges. Kulakowski \& Veblen (2002), Evans et al. (2007), and Lenart et al. (2010) observed an increase in the proportion of windthrow damage at higher elevations. In the studied area the role of elevation in the localization of windthrow damage is mainly expressed in the decrease in the amount of damage within the highest elevation intervals which is mostly distinctive for the three analyzed periods. This is probably connected with the presence of the upper timber line, which is located on average at an altitude of 1550 m a.s.l. (Balon 1995), near which the uprooting of trees is quite uncommon (Schaetzl et al. 1989b). In the same three periods the largest damage occurred at an altitude of 1000-1150 m a.s.l., which is similar to the results obtained by Bzowski \& Dziewolski (1973) for the catastrophic foehn wind that occurred in the Tatra Mountains in 1968. The reason of that may be the presence of spruce monocultures in the lowest part of the Polish Tatra Mountains (see section Study area), which should be naturally overgrown by deciduous forest with the dominance of beech (Mirek 1996). Perhaps artificially introduced species are not adapted to the local conditions and thus are more prone to damage. A decrease in the proportion of damage within the lowest elevations may be also caused by lower wind speed within deep and narrow valleys whose axes are perpendicular to the wind direction (Ruel et al. 1998), and which are numerous in the study area.

The impact of canopy gaps on the forest dynamics was a subject of many studies. Worrall et al. (2005) showed that although the creation of natural canopy gaps is in most cases connected with tree diseases, the occurrence of bark beetle, or parasitic plants, their expansion is mostly caused by the action of wind. The occurrence of wide spaces between trees, however, does not always lead to their higher instability. Achim et al. (2005) showed that wider tree spacing led to an increase of critical wind force needed for trunk breakage. In the case of uprooting, however, this increase was lower. Gardiner et al. (1997) showed that wider tree spacing led to a decrease in susceptibility to trunk breakage, and an increase in susceptibility to uprooting. Cremer (1977, 1982) pointed out that trees in thinned stands are susceptible to wind damage in the period immediately after thinning operations. However, if these sites remain undisturbed for some period, trees bordering gaps may become adapted to wind even better than those growing in unthinned stands.

In the study area no significant relation was found in the proportion of an area occupied by canopy gaps between pre-windthrow areas and their reference areas, which may suggest that this factor had a rather secondary influence on the distribution of windthrow damage. Nonetheless, because of methodological limitations, this analysis was conducted for only part of the whole dataset (see Methods section), and therefore, 
it is possible that the overall effect of gaps was more explicit.

Forest edges were in many studies noted as vulnerable areas, where wind damage occurred more frequently than elsewhere (Alexander 1964; DeWalle 1983; Ruel et al. 2001; Pawlik 2012). Increased windthrow occurrence was reported both within forest edges created by clearcutting operations (Alexander 1964; DeWalle 1983) and within forest edges created by recent windthrow (Kwiatkowski 1969; Greene et al. 1992). Studies of wind forces and behaviour showed that trees growing at the edge of a forest experience far more wind loading than trees within a forest. However, wind loading decreases rapidly with the distance from the forest edge into the forest, as trees become more sheltered (Stacey et al. 1994; Gardiner et al. 1997). If trees at a forest edge remain undisturbed for a longer period they may become adapted to wind conditions, similarly to trees bordering a canopy gap (Cremer et al. 1977; Urban et al. 1994). In the study area a large proportion of windthrow patches were created at the edges of the forest. This proportion was exceptionally high (88\%) in the period D, 1.5 years before which an extensive windthrow event occurred. Moreover, all of the windthrow areas created in the period $D$, were located in the direct neighbourhood of windthrow areas created in the period C. This would suggest that the presence of forest edges, especially those which were created recently, may be one of the primary factors controlling the location of damage in the forests.

\section{Conclusions}

Damage in the forests caused by the action of wind is not uniformly distributed. It is difficult, however, to point to the factor which mostly influences the distribution of windthrow damage. Both abiotic and biotic factors may control the location of damage, and they may all act together, creating complex relations. Nevertheless, there certainly are features which are more important than others. In this study the most important topographic feature influencing the distribution of wind damage was the aspect. The role of the slope, and the elevation was also noted, but their significance was limited to the most gentle and the steepest slopes, and to the lowest and the highest elevations.

One of the most important relations observed within the analyzed periods is the frequent occurrence of windthrows within forest edges and the common expansion of windthrow areas in those sites. This confirms earlier remarks about the vulnerability of forest edges, created both by logging and by recent wind damage, and shows that these sites, especially freshly created edges, are the places where further damage is mostly expected. The role of canopy gaps was not unequivocal in the analyzed periods, and thus of rather secondary importance.

There is a need for further investigation of the distribution of wind damage, especially the mapping of damaged areas immediately after their creation which would make it possible to assign meteorological data to each of them. Also a longer period of monitoring would be necessary so as to more comprehensively explain the complex relations controlling the spatial distribution of wind damage.

\section{Acknowledgements}

The paper makes use of meteorological data provided by the Institute of Meteorology and Water Management - State Research Institute (IMGW-PIB).

Editors' note:

Unless otherwise stated, the sources of tables and figures are the authors', on the basis of their own research. 


\section{References}

Achim A., Ruel J-C., Gardiner B.A., 2005. Evaluating the effect of precommercial thinning on the resistance of balsam fir to windthrow through experimentation, modelling, and development of simple indices. Canadian Journal of Forest Research, vol. 35, no. 8, pp. 18441853.

AleXANDer R.R., 1964. Minimizing windfall around clear cuttings in Spruce-Fir forests. Forest Science, vol. 10, no. 2, pp. 130-142.

Bac-Moszaszwill M., Burchart J., Głazek J., IWAnow A., Jaroszewski W., Kotański Z., Lefeld J., Mastella L., Ozimkowski W., Roniewicz P., SkUpiński A., Westwalewicz-Mogilska E., 1979. Mapa geologiczna Tatr Polskich, 1:30,000. Warszawa: Wydawnictwa Geologiczne.

BALON J., 1995. The upper forest limit in the Tatra Mountains as a physico-geographical line. Prace Geograficzne, vol. 98, pp. 171-187.

Balon J., Maciejowski W., 2005. Wpływ huraganowego wiatru z dnia 19 listopada 2004 na krajobraz południowego skłonu Tatr. Problemy Ekologii Krajobrazu, vol. 17, pp. 92-100.

Bzowskı M., DzIewolskı J., 1973. Zniszczenia w lasach Tatrzańskiego Parku Narodowego spowodowane przez wiatr halny wiosna $1968 \mathrm{r}$. Ochrona Przyrody, vol. 38, pp. 115-154.

CIURZYCKI W., 2003. Gospodarka pasterska a lasy Tatr Polskich. Sylwan, vol. 147, no. 11, pp. 80-85.

Clinton B.D., Baker C.R., 2000. Catastrophic windthrow in the southern Appalachians: characteristics of pits and mounds and initial vegetation responses. Forest Ecology and Management, vol. 126, no. 1, pp. 51-60.

CODGIK, 2017a. Ortofotomapa. Centralny Ośrodek Dokumentacji Geograficznej i Kartograficznej, http://codgik.gov.pl/index.php/zasob/ ortofotomapa.html [12 September 2017].

CODGIK, 2017b. Numeryczne dane wysokościowe. Centralny Ośrodek Dokumentacji Geograficznej i Kartograficznej, http://codgik.gov.pl/ index.php/zasob/numeryczne-dane-wysokosciowe.html [27 November 2017].

Cremeans D.W., Kalisz P.J., 1988. Distribution and characteristics of windthrow microtopography on the Cumberland Plateau of Kentucky. Soil Science Society of America Journal, vol. 52, no. 3, pp. 816-821.
Cremer K.W., Meyers B.J., Van der Duys F., Craig I.E., 1977. Silvicultural lessons from the 1974 windthrow in radiata pine plantations near Canberra. Australian Forestry, vol. 40, no. 4, pp. 274-292.

Cremer K.W., Borough C.J., McKinnell F.H., CARTER P.R., 1982. Effects of stocking and thinning on wind damage in plantations. New Zealand Journal of Forestry Science, vol. 12, no. 2, pp. 244-268.

Denny C., Goodlett J., 1956. Microrelief resulting from fallen trees. USGS Professional Publication, vol. 288, pp. 59-68.

DeWalle D.R., 1983. Wind damage around clearcuts in the ridge and valley province of Pennsylvania. Journal of Forestry, vol. 81, no. 3, pp. 158-159.

Everham E.E., Brokaw N.V.L., 1996. Forest damage and recovery from catastrophic wind. Botanical Review, vol. 62, no. 2, pp. 113-185.

Evans A.M., Camp A.E., Tyrrell M.L., Riley C.C., 2007. Biotic and abiotic influences on wind disturbance in forests of NW Pennsylvania, USA. Forest Ecology and Management, vol. 245, no. 1-3, pp. 44-53.

Falťan V., Katina S., Bánovský M., Pazúrová Z., 2009. The influence of site conditions on the impact of windstorms on forests: the case of the High Tatras foothills (Slovakia) in 2004. Moravian Geographical Reports, vol. 17, no. 3, pp. 10-18.

FOREST DATA BANK, 2017. https://www.bdl.lasy.gov. $\mathrm{pl} /$ portal/ [12 October 2017].

Foster D.R., Boose E.R., 1992. Patterns of forest damage resulting from catastrophic wind in central New England, USA. Journal of Ecology, vol. 80, no. 1, pp. 79-98.

FreliCH L.E., LoRIMER C.G., 1991. Natural disturbance regimes in hemlock hardwood forests of the upper Great-Lakes Region. Ecological Monographs, vol. 61, no. 2, pp. 145-164.

Gabet E.J., Mudd S.M., 2010. Bedrock erosion by root fracture and tree throw: A coupled biogeomorphic model to explore the humped soil production function and the persistence of hillslope soils. Journal of Geophysical Research, vol. 115, no. F4, pp. 1-14.

Gardiner B.A., Stacey G.R., Belcher R.E., Wood C.J., 1997. Field and wind tunnel assessments of the implications of respacing and 
thinning for tree stability. Forestry, vol. 70, no. 3, pp. 233-252.

Greenberg C.H., McNab W.H., 1998. Forest disturbance in hurricane-related downbursts in the Appalachian mountains of North Carolina. Forest Ecology and Management, vol. 104, no. 1, pp. 179-191.

HaVašová M., Ferenčík J., JaKuš R., 2017. Interactions between windthrows, bark beetles and forest management in the Tatra national parks. Forest Ecology and Management, vol. 391, no. 1, pp. 349-361.

Hess M., 1974. Piętra klimatyczne Tatr. Czasopismo Geograficzne, vol. 45, no. 1, pp. 75- 93.

JANE G.T., 1986. Wind damage as an ecological process in mountain beech forests of Canterbury, New Zealand. New Zealand Journal of Ecology, vol. 9, pp. 25-39.

KlimASZEWSKI M., 1972. Karpaty Wewnętrzne [in:] M. Klimaszewski (ed.), Geomorfologia Polski, tom 1, Polska Południowa. Góry i Wyżyny, pp. 24-52.

KotARBA A., 1970. The morphogenetic role of foehn wind in the Tatra Mts. Studia Geomorphologica Carpatho-Balcanica, vol. 4, pp. 171-188.

Krameko SP. z O.O., 2005. Dokumentacja urzadzeniowa Lasów Skarbu Państwa Tatrzańskiego Parku Narodowego na okres od 1 stycznia 2006 roku do 31 grudnia 2025 roku. Zakopane.

Kramer M.G., Hansen A.J., Taper M.L., KissINGER E.J., 2001. Abiotic controls on long-term windthrow disturbance and temperate rain forest dynamics in Southeast Alaska. Ecology, vol. 82 , no. 10, pp. 2749-2768.

KULAKOWSKI D., VEBLEN T.T., 2002. Influences of fire history and topography on the pattern of a severe wind blowdown in a Colorado subalpine forest. Journal of Ecology, vol. 90, no. 5, pp. 806-819.

KWIATKOWSKI J., 1969. Klimatologiczna geneza wyłomów leśnych w Karkonoszach. Czasopismo Geograficzne, vol. 40, no. 3, pp. 365-373.

Lenart M.T., Falk D.A., Scatena F.N., Osterkamp W.R., 2010. Estimating soil turnover rate from tree uprooting during hurricanes in Puerto Rico. Forest Ecology and Management, vol. 259, no. 6, pp. 1076-1084.

Minár J., Falťan V., Bánovský M., DamankošoVÁ Z., KožUCH M., 2009. Influence of site conditions on the windstorm impact: A case study of the High Tatras foothills in 2004. Landform Analysis, vol. 10, pp. 95-101.

MIREK Z., 1996. Tatry i Tatrzański Park Narodowy - wiadomości ogólne [in:] Z. Mirek, Z. Głowaciński, K. Klimek, H. Piękoś-Mirkowa (eds.), Przyroda Tatrzańskiego Parku Narodowego. Tatrzański Park Narodowy, Zakopane: Tatrzański Park Narodowy, pp. 17-26.

Nicoll B.C., Achim A., Mochan S., GardinER B.A., 2005. Does steep terrain influence tree stability? A field investigation. Canadian Journal of Forest Research, vol. 35, no. 10, pp. 2360-2367.

NiedźWiedź T., 1992. Climate of the Tatra Mountains. Mountain Research and Development, vol. 12, no. 3, pp. 131-146.

Norman S.A., Schaetzl R.J., Small T.W., 1995. Effects of slope angle on mass movement by tree uprooting. Geomorphology, vol. 14, no. 1, pp. 19-27.

Økland B., Nikolov C., Krokene P., Vakula J., 2016. Transition from windfall- to patch-driven outbreak dynamics of the spruce bark beetle Ips typographus. Forest Ecology and Management, vol. 363, no. C, pp. 63-73.

PapaIK M.J., CANHAM C.D., LatTy E.F., Woods K.D., 2005. Effects of an introduced pathogen on resistance to natural disturbance: Beech bark disease and windthrow. Canadian Journal of Forest Research, vol. 35, no. 8, pp. 1832-1843.

PAwLIK Ł., 2012. Przekształcenia powierzchni stokowych $w$ Sudetach $w$ wyniku procesu saltacji wykrotowej. Landform Analysis, vol. 20, pp. 79-94.

Pawlik Ł., Migoń P., Szymanowski M., 2016. Local- and regional-scale biomorphodynamics due to tree uprooting in semi-natural and manager montane forest of the Sudetes Mountains, Central Europe. Earth Surface Processes Landforms, vol. 41, no. 9, pp. 1250-1265.

Peterson C.J., 2007. Consistent influence of tree diameter and species on damage in nine eastern North America tornado blowdowns. Forest Ecology and Management, vol. 250, no. 1-2, pp. 96-106.

Phillips J.D., Marion D.A., 2004. Pedological memory in forest soil development. Forest Ecology and Management, vol. 188, no. 1-3, pp. 363-380. 
Phillips J.D., LUCKOW K., Marion D.A., AdAms K.R., 2005. Rock fragment distributions and regolith evolution in the Ouachita Mountains. Earth Surface Processes and Landforms, vol. 30, no. 4, pp. 429-442.

Phillips J.D., Marion D.A., Yocum C., MehlHOPE S.H., OLSON J.W., 2015. Geomorphological impacts of a tornado disturbance in a subtropical forest. Catena, vol. 125, pp. 111-119.

Phillips J.D., Šamonil P., PAWlik Ł., Trochta J., DANĚK P., 2017. Domination of hillslope denudation by tree uprooting in an old-growth forest. Geomorphology, vol. 276, no. 1, pp. 27-36.

PuTz F.E., 1983. Treefall pits and mounds, buried seeds, and the importance of soil disturbance to pioneer trees on Barro Colorado Island, Panama. Ecology, vol. 64, no. 5, pp. 1069-1074.

Ruel J.-C., Pin D., Cooper K., 1998. Effect of topography on wind behaviour in a complex terrain. Forestry, vol. 71, no. 3, pp. 261-265.

Ruel J.-C., PIn D., COOPER K., 2001. Windthrow in riparian buffer strips: effect of wind exposure, thinning and strip width. Forest Ecology and Management, vol. 143, no. 1-3, pp. 105-113.

ŠAMONIL P., KRÁL K., HORT L., 2010. The role of tree uprooting in soil formation: a critical literature review. Geoderma, vol. 157, no. 3-4, pp. 65-79.

SchaetZl R.J., JOHnSON D.L., BuRns S.F., Small T.W., 1989a. Tree uprooting: Review of terminology, process, and environmental implications. Canadian Journal of Forest Research, vol. 19, no. 1, pp. 1-11.

SchaetZl R.J., Burns S.F., Johnson D.L., Small T.W., 1989b. Tree uprooting: Review of impacts on forest ecology. Vegetatio, vol. 79, no. 3 , pp. 165-176.
SkIBA S., 2002. Mapa gleb Tatrzańskiego Parku Narodowego [in:] W. Borowiec, A. Kotarba, A. Kownacki, Z. Krzan, Z. Mirek (eds.), Przemiany środowiska przyrodniczego Tatr. Kraków-Zakopane: Tatrzański Park Narodowy, Polskie Towarzystwo Przyjaciół Nauk o Ziemi, pp. 21-26.

SokOŁowski M., 1934. Szkody od powału w lasach tatrzańskich i sposoby zapobiegania im w zakresie hodowli lasu. Prace Rolniczo-Leśne, vol. 10, Kraków: Polska Akademia Umiejętności.

Stacey G.R., Belcher R.E., Wood C.J., GardinER B.A., 1994. Wind flows and forces in a model spruce forest. Boundary-Layer Meteorology, vol. 69, no. 3, pp. 311-334.

Strzyżowski D., Fidelus-Orzechowska J., ŻelaZNY M., 2018. Sediment transport by uprooting in the forested part of the Tatra Mountains, southern Poland. Catena, vol. 160, no. C, pp. 329-338.

ULANOVA N.G., 2000. The effects of windthrow on forests at different spatial scales: a review. Forest Ecology and Management, vol. 135, no. 1-3, pp. 155-167.

Urban S.T., LiefFers V.J., MacDonald S.E., 1994. Release in radial growth in the trunk and structural roots of white spruce as measured by dendrochronology. Canadian Journal of Forest Research, vol. 24, no. 8, pp. 1550-1556.

Worrall J.J., Lee T.D., Harrington T.C., 2005. Forest dynamics and agents that initiate and expand canopy gaps in Picea-Abies forests of Crawford Notch, New Hampshire, USA. Journal of Ecology, vol. 93, no. 1, pp. 178-190. 